\title{
Formation of Storage Protein Components during Soybean Seed Development
}

\author{
Sonoe Ochial-Yanagi, Chikafusa Fukazawa and Kyuya Harada* \\ National Food Research Institute, Ministry of Agriculture and Forestry, \\ Koto-ku, Shiohama 1, Tokyo 135 \\ *Faculty of Agriculture, The University of Tokyo, Bunkyo-ku Yayoi 1, Tokyo 113
}

Received July 8, 1977

\begin{abstract}
Formation and accumulation of protein components and their subunits in developing soybean seeds were investigated ultracentrifugally, electrophoretically and immunologically from flowering until maturity. Glycine max var. Ogura daizu took 80 to 90 days after flowering to mature its seeds. Only smaller molecular weight components were observed until 26 days after flowering in ultracentrifugal and electrophoretical patterns. Components of about $7 \mathrm{~S}$ and $12 \mathrm{~S}$ appeared 33 days after flowering. Immunological studies and sodium dodecyl sulfate electrophoresis, however, indicated that the specificities as antigens and subunit constituents of these components were different from those of the matured $7 \mathrm{~S}$ and $11 \mathrm{~S}$ globulins. Immunological specificity of mature $7 \mathrm{~S}$ globulin was obviously detected 40 days after flowering, and that of $11 \mathrm{~S}$ globulin was seen 50 days after flowering at least. These storage protein components were intensively accumulated from 40 days after flowering until maturity.
\end{abstract}

A large amount of protein(from 30 to more than $50 \%$ of dry weight) is contained in mature soybean seeds. ${ }^{1)}$ The synthesis and accumulaation of protein, therefore, is one of the main events of metabolism during seed development of soybean. Biochemical studies on soybean seed development are expected to present an interesting system for investigation of storage protein biosynthesis and regulation of protein biosynthesis.

Storage protein of soybean seeds is accumulated in subcellular particles, protein bodies. ${ }^{2}$ Major protein components of mature soybean seeds, 7S globulin and 11S globulin, have been investigated from various points of view, and other minor components of soybean seed protein are also known. ${ }^{3 \sim 7}$ ) The two major components, $7 \mathrm{~S}$ and $11 \mathrm{~S}$ globulin, constitute more than $70 \%$ of soybean storage protein, and studies on subunits structure ${ }^{8 \sim 10)}$ and immunochemical properties ${ }^{11,12)}$ of these proteins have been reported.

In contrast to extensive studies on chemical, physical or food-technological properties of soybean protein, little is known about the bio-

Abbreviation: SDS, sodium dodecyl sulfate. synthesis of soybean protein during seed development. Electrophoretical studies on protein changes and sedimentation diagrams of protein changes in sucrose density gradient centrifugation and in ultracentrifugation were described in a few papers. ${ }^{13 \sim 15}$;

Glycine max var. Ogura daizu is a late ripening variety and takes 80 to 90 days after flowering to mature its seeds. Seeds of Ogura daizu were collected at several stages of their developing period. Extracted protein from the seeds were studied abreast by analytical ultracentrifugation, by electrophoreses with or without sodium dodecyl sulfate (SDS) and by immunological techniques. All the results were compared and discussed together.

\section{MATERIALS AND METHODS}

Materials. SDS, specially prepared reagent SPS -4 was obtained from Nakarai Chemicals, and other chemicals were guaranteed commercial products. Seeds of Glycine max var. Ogura daizu, obtained from the seed stocks of Kikyogahara-branch, Nagano-prefecture Agricultural Experiment Station, were planted in the fields of Tokyo University. After 46 days, fully expanded flowers were seen at the 4th, 5th, 6th and 7th nodes, numbered from the top, and the soybean plants 
were divided into six groups. Pods developed from the flowers of these nodes were harvested, 26, 33, 40, 50,61 and 87 days after flowering, only once from each of the six groups of soybean plants. Seeds were deppoded, and those of immoderate sizes were excluded from the sample soybeans.

Dry weight. Dry weight was determined by placing freshly weighed seeds in a $105^{\circ} \mathrm{C}$ drying oven in vacuum, weighing $5 \mathrm{hr}$ later, and reweighing until the weight was constant.

Nitrogen content. Total nitrogen was measured by the Micro-Kjeldahl method. ${ }^{19}$ )

Whole protein extraction. Fifty grams of soybean sceds were ground in a chilled mortar with washed sea sand, and $75 \mathrm{ml}$ of cold buffer A (Wolf's standard buffer $^{17)}: 35 \mathrm{~mm}$ potassium phosphate buffer with $0.4 \mathrm{M}$ sodium chloride and $10 \mathrm{~mm}$ mercaptoethanol, pH 7.6) was added. Cell debris was separated by centrifugation at $5000 \times g$ for $30 \mathrm{~min}$, ground again and reextracted. The combined supernatant was filtered through a filter paper (Toyo No. 5A), and centrifuged at $25,000 \times g$ for $30 \mathrm{~min}$. Lipid in the supernatant was extracted with $n$-hexane through a separatory funnel for three times. The aqueous layer was centrifuged at $50,000 \times \mathrm{g}$ for $1 \mathrm{hr}$, and the clear middle layer was taken and dialyzed against buffer $A$.

Uitracentrifugal analysis. Pictures of sediment. ation profiles of protein solutions, obtained from the $50,000 \times g$ supernatant and dialyzed, were taken in a Hitachi ultracentrifuge UCA 1A with a double sector cell and a shlieren optical system at a speed of $51,000 \mathrm{rpm}$ at $20^{\circ} \mathrm{C}$. Six pictures for one run were taken at the intervals of $9 \mathrm{~min}$ after reaching the speed of $51,000 \mathrm{rpm}$ to calculated Svedberg units.

Electrophoresis. The same protein solutions as ultracentrifuge samples were analyzed by electrophoresis with or without SDS in $7.5 \%$ polyacrylamide gel. The glass tubes were $10 \mathrm{~cm}$ long with an inner diameter of $6 \mathrm{~mm}$. For the procedure without SDS, Davis's method $^{13)}$ was followed at pH 8.9 (Tris-glycine buffer). Sample proteins were kept in buffer $A$ at least overnight. ${ }^{18)}$ SDS electrophoresis was carried out essentially by the method of Weber and Osborn. ${ }^{20)}$ Protein samples were denatured with $2 \%$ SDS in 10 mM sodium phosphate buffer, pH 7.2, containing $2 \%$ mercaptoethanol, overnight at room temperature or $5 \mathrm{~min}$ at $90^{\circ} \mathrm{C}$. Staining dye was coomassie brilliant blue R-250 or amide black 10B. The destained gels were scanned on an Asuka-Ozumor 8 densitometer.

Immunological analysis. Random bred albino rabbits, weighing $2.5 \mathrm{~kg}$ to $3.1 \mathrm{~kg}$, were immunized with two kinds of $7 \mathrm{~S}$ proteins ( $\beta$ - and $\gamma$-conglycinins ${ }^{21)}$ ) and
11S protein (glycinin). These proteins were prepared in an electrophoretically homogeneous state by the method of fractional acid precipitation and gel filtration (Fukazawa et al., manuscript in preparation). Freund's complete adjuvant ${ }^{22}$ was prepared by mixing 9 parts of Bayol F, 1 part of Arlacel A and $10 \mathrm{mg}$ of autoclaved Mycobacterium tuberculosis per $\mathrm{ml}$. Five or $10 \mathrm{mg}$ of antigen protein in $1 \mathrm{ml}$ of $0.5 \mathrm{M}$ sodium chloride solution was mixed with an equal volume of the adjuvant in a Waring blendor, and weekly injected into several intramuscular sites for 3 weeks. A constant amount of antigen in a dose was given to each rabbit. After a one-month rest, rabbits were reinjected subcutaneously on four foot-pads and the back with the same amount of the antigen and adjuvant mixture twice at a one-week interval. The rabbits were bled two weeks after the last injection. The antiserum was kept at $56^{\circ} \mathrm{C}$ for $1 \mathrm{hr}$ to destroy endogenous complement and stored at $0^{\circ} \mathrm{C}$ with a final concentration of $0.01 \%$ merthiolate. Simple radial inmunodiffusion described by Mancini et al..$^{23)}$ was performed for a quantitative analysis of each protein. A suitable dilution of antiserum made in $0.02 \mathrm{M}$ barbital buffer, $\mathrm{pH} 8.2$, containing $1.0 \mathrm{M}$ sodium chloride was mixed with agar solution in the same buffer. Final agar concentration was $1 \%$, and the treating temperature was $60^{\circ} \mathrm{C}$. The mixture was poured into a mold of $1 \times 84 \times 62 \mathrm{~mm}$. After solidification, circular wells of $2 \mathrm{~mm}$ in diameter were punched out in the gel. Each well received $2 \mu$ of antigen solution, and the plate was kept in a horizontal position for 10 to $30 \mathrm{~min}$. Then the plate was immersed in paraffin oil and stored at $20^{\circ} \mathrm{C}$ for $72 \mathrm{hr}$. After removing the oil by a short rinse in petroleum ether, the diameter of the ring-shaped precipitates around the antigen well was measured.

\section{RESULTS}

Seeds of Glycine max var. Ogura daizu matured about 85 days after flowering, and their dry weight and nitrogen content rapidly increased from 40 days after flowering until maturity (Fig. 1). The nitrogen percentages to dry weights were approximately constant, $7.3 \pm 0.6$, throughout the growing period. The dry weight and nitrogen content of smaller seeds on the 26 th day were almost the same as those of moderate seeds. The dry weight percent of matured natural dry seeds of Ogura daizu, more than a year after the harvest, was $90.8 \%$, and the nitrogen percentage to the dry weight was also within $7.3 \pm 0.6$.

Figure 2 shows ultracentrifuge patterns of whole seed extract at various stages of matura- 

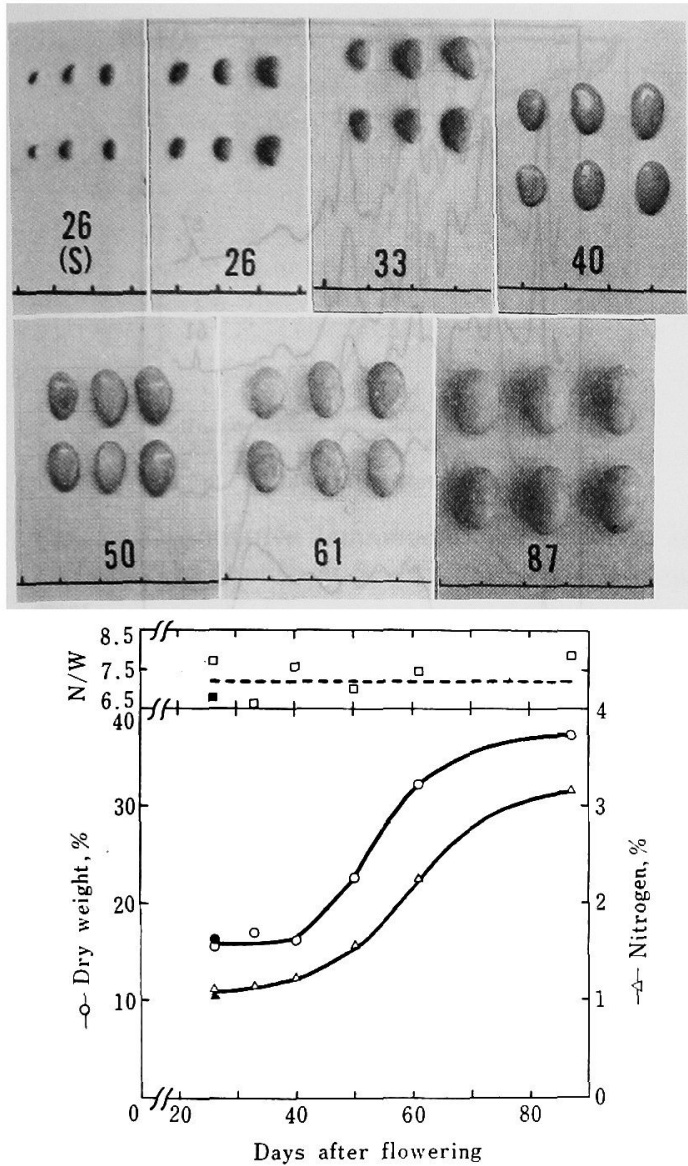

FIG. 1. Pictures of Seeds, Dry Weight and Total Nitrogen Content during Seed Development of Glycine max var. Ogura Daizu.

Numbers in the pictures are days after flowering, and $\mathrm{S}$ is the abbreviation of small seeds. One section of scale in the pictures is $1 \mathrm{~cm}$. N/W represents nitrogen content to dry weight. $\mathrm{O}-\mathrm{O}$ and (small seeds), dry weight $\%: \triangle-\triangle$ and $\boldsymbol{\Delta - \Lambda}$ (small seeds), nitrogen $\%$ of fresh weight.

tion. Before the 33rd day relatively smaller molecule component(s) was/were present. Only a peak was seen, and calculated $S_{20}$ at the condition measured (see MATERIALS AND METHODS) was 4.2. As the peak was broad, however, the component(s) did not seem to be simple. The pattern on the 33rd day presented at least three sedimenting components $(3.3 \mathrm{~S}, 7.0 \mathrm{~S}$ and 12.2S). After the 40th day, the accumulation of $6.5 \sim 7.5 \mathrm{~S}$ and $11 \sim 12 \mathrm{~S}$ components were seen. The relative amount of smaller molecule component's) (2 4) gradually decreased with

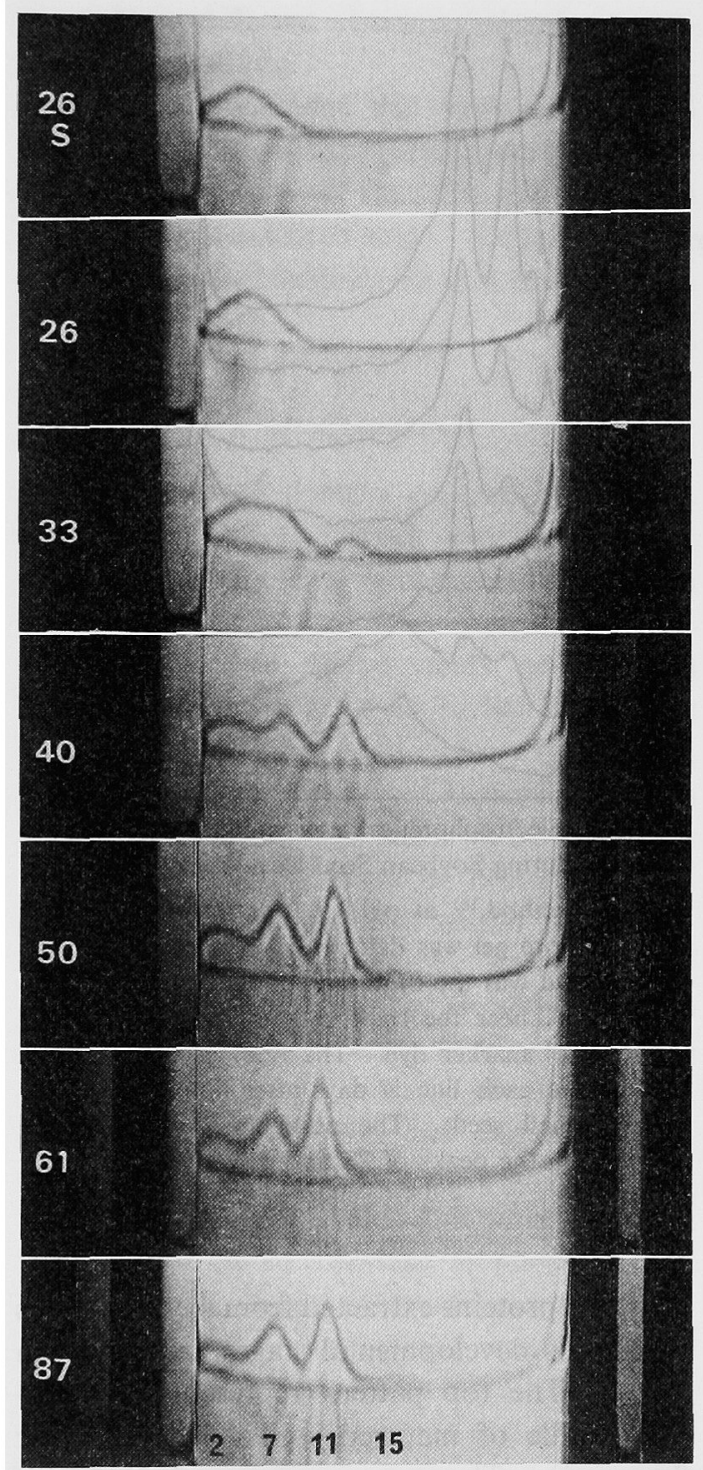

FiG. 2. Ultracentrifuge Sedimentation Diagrams of Whole Seed Extracts at Various Stages of Development.

Solvent was $35 \mathrm{~mm}$ phosphate buffer, $0.4 \mathrm{M}$ sodium chloride and $10 \mathrm{~mm}$ mercaptoethanol. Pictures were taken at a speed of $51,000 \mathrm{rpm}$ at $20^{\circ} \mathrm{C} 36 \mathrm{~min}$ after reaching the maximum speed. The number on the left of each picture is days after flowering, and $\mathrm{S}$ is small seeds. Numbers across the bottom of pattern are sedimentation coefficients in Svedberg units.

maturity. A very small amount of larger molectle component (15S) was seen 50 days after flowering.

Polyacrylamide gel electrophoresis patterns 


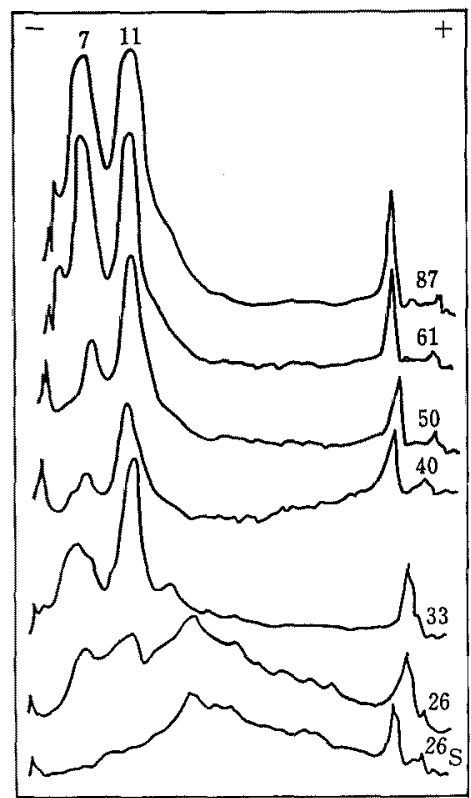

Fig. 3. Electrophoretic Patterns of the Whole Seed Proteins during Soybean Seed Development.

Davis's method, ${ }^{18)}$ at $\mathrm{pH} 8.9$, was mainly followed. A large pore gel was detached before scanning, and the left end was the beginning of running gels. The sharp peak near the right end of each gel was the position of marker dye. The number on the right side above each line is days after flowering, and $\mathbf{S}$ means small seeds. The numbers 7 and 11 correspond to the peaks of $7 \mathrm{~S}$ and $11 \mathrm{~S}$ proteins respectively. ${ }^{10)}$

of whole proteins extracted from soybean seeds at various developmental stages are shown in Fig. 3. The top pattern represents the protein profile of matured seeds ( 87 days after flowering). The two major peaks of this pattern correspond to $7 \mathrm{~S}$ and $11 \mathrm{~S}$ components (Hashizume et al. analyzed heated and unheated soybean protein by ultracentrifugation and electrophoresis which are essentially the same methods as used in this work, and showed the correspondence of these protein components in these two analyses $\left.{ }^{19}\right)$ ). Mobilities of major peaks at early stages of development had small deviations from those of the matured. Relative amounts of the two main components on electrophoresis patterns did not reflect those of ultracentrifuge patterns. These results suggest that the apparent $7 \mathrm{~S}$ and $11 \mathrm{~S}$ components

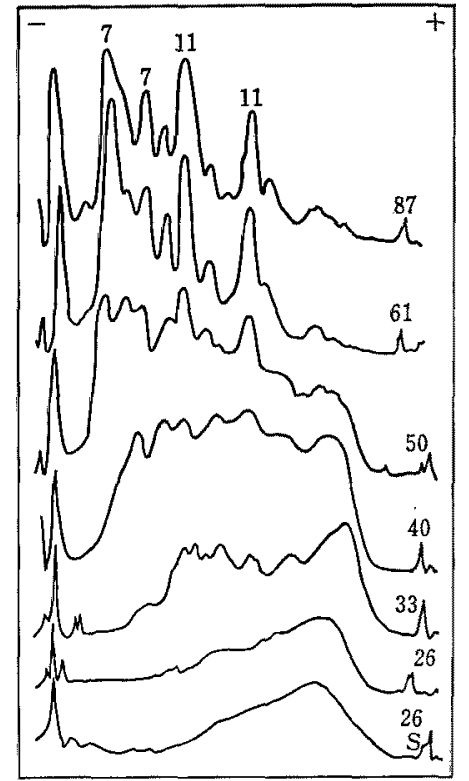

Fig. 4. Densitometric Patterns of Electrophoresed Soybean Seed Protein Subunits at Vavious Stages of Seed Development.

Whole seed proteins were pretreated with $2 \%$ SDS, and electrophoreses were run in a $7.5 \%$ polyacrylamide gel with $0.1 \%$ SDS in a buffer of $\mathrm{pH} 7.2$. The numbers 7 and 11 above the peaks indicate the major subunits of $7 \mathrm{~S}$ protein ${ }^{10)}$ and $11 \mathrm{~S}$ protein, ${ }^{24)}$ respectively. The right side numbers are days after flowering, and $S$ represents small seeds.

of immatured seeds have different properties from those of matured ones.

Figure 4 shows electrophoretic patterns of whole seed extract with SDS on the indicated days after flowering. Both $7 \mathrm{~S}$ and $11 \mathrm{~S}$ globulins in SDS solution consist of two major and other minor subunits respectively. ${ }^{10,24}$ One of the major subunits of $7 \mathrm{~S}$ component was not seen in the patterns of before the 50th day, though $7 \mathrm{~S}$ component was already seen in the ultracentrifuge pattern of the 40 th or $33 \mathrm{rd}$ day (Fig. 2). It is suggested that the results of SDS electrophoresis also represent the difference between $7 \mathrm{~S}$ component of immatured stages and that of matured stages. Two presumable major subunits of $11 \mathrm{~S}$ globulin appeared in the pattern of the 40th day at least or the 33rd day slightly. This is consistent with the results of Fig. 2 and Fig. 3. 


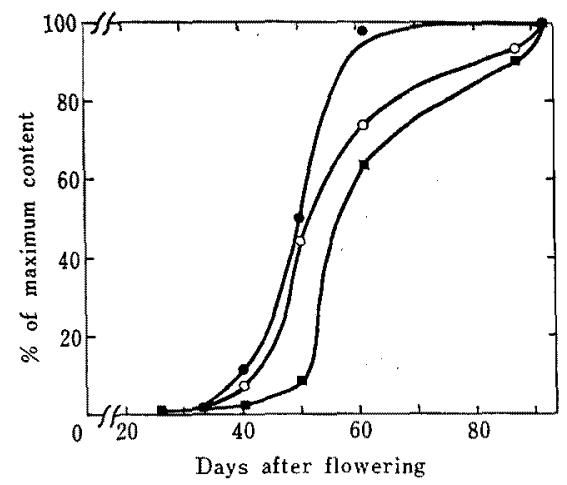

Fig. 5. Quantitative Immunodiffusion Analyses of Soybean Seed Protein at Several Stages of Development.

Quantitative immunodiffusion was carried out by the method of Mancini et al ${ }^{23)}$ (Details are described in Materials and Methods). Anti-7S protein rabbit serum or anti-11S protein rabbit serum was used to immunoprecipitate $7 \mathrm{~S}$ or $11 \mathrm{~S}$ protein synthesized at various stages of development. ' $\%$ of Maximum Content' represents the relative amount of each immunoprecipitated protein at the stage of development to the corresponding matured protein.

$\gamma$-conglycinin (7S globulin) ${ }^{21)} ; \bigcirc-\mathrm{O}, \beta$-conglycinin $(7 \mathrm{~S} \text { globulin })^{21)} ; \mathbf{\square}-\mathbf{n}$, glycinin (11S globulin).$^{21)}$

Anti-serum of $7 \mathrm{~S}$ or $11 \mathrm{~S}$ globulin from matured seeds was obtained from rabbits which were immunized with each protein. As $7 \mathrm{~S}$ globulins with different properties have been reported and named $\beta$-conglicinin and $\gamma$ conglicinin, ${ }^{21)}$ an anti-serum for each individual $7 \mathrm{~S}$ globulin was prepared. The amount of $7 \mathrm{~S}$ or $11 \mathrm{~S}$ component, which has a property to immunoprecipitate with the correspondent anti-serum, was measured by a quantitative immunodiffusion method ${ }^{23)}$ (details in MATERIALS AND METHODS) at various stages of development. As shown in Fig. 5, both types of $7 \mathrm{~S}$ globulin were detected 40 days after flowering and increased very rapidly from that stage on. No substantial immunoprecipitation with anti-11S globulin was detected until 50 days after flowering, and a rapid increase was also seen from that time on. Thus immunochemical technique also explains that $11 \mathrm{~S}$ components observed in sedimentation diagrams of ultracentrifugation and in electrophoresis patterns at early stages of develop- ment have different characteristics from matured $11 \mathrm{~S}$ globulin.

It can be concluded that approximately $7 \mathrm{~S}$ and $11 \mathrm{~S}$ components appeared at early developmental stages were not the same as $7 \mathrm{~S}$ and $11 \mathrm{~S}$ globulins at a matured stage. Differences were seen in subunit construction and immunological property.

\section{DISCUSSION}

The estimated protein content of soybean seeds treated in this work was $45.6 \pm 3.8 \%$, 6.25 times the Kjeldahl nitrogen value. As the contents of low molecular weight nitrogen compounds (free amino acids and others) seemed to be greater at an earlier stage than at a later stage in our preliminary experiments, the nitrogen percentage fixed as storage protein seemed to increase with maturation. A linear and considerable increase of nitrogen in trichloroacetic acid insoluble fraction was reported by Asano and Shibasaki. ${ }^{14)}$ An increase of total nitrogen and changes in sedimentation diagrams of protein during development were also similar to the results of Asano and Shibasaki ${ }^{14}$ and of Hill and Breidenbach, ${ }^{15}$ though the soybean strain used was different.

Relations between the components which have the Svedberg constant of about $7 \mathrm{~S}$ and $11 \mathrm{~S}$ at earlier stages of development and the $7 \mathrm{~S}$ and $11 \mathrm{~S}$ globulins at the matured stage are to be investigated. As mentioned in the RESULTS, the subunit structure and antigenisity of the former differ from those of the latter. Since the net amount of protein at earlier stages of development is very small, it is probable and not contradictory to regard that $7 \mathrm{~S}$ and $11 \mathrm{~S}$ components at early stages have no direct relation to $7 \mathrm{~S}$ and $11 \mathrm{~S}$ globulins at the matured stage. But the possibility of 7S and $11 \mathrm{~S}$ components at early stages being precursors of $7 \mathrm{~S}$ and $11 \mathrm{~S}$ globulins at the matured stage is undeniable either. The difference in fine chemical structures between these proteins is to be studied in the future.

What are the details of protein synthesis and regulation at various stages of seed develop- 
ment? Beevers and Poulson suggested the possibility of both mRNA level and translational level regulation in the studies on protein synthesis in cotyledons of Pisum sativum L. $^{25)}$ Fukazawa et al. (manuscripts in preparation) separated poly A-RNA from seeds of Glycine max L. at various stages of maturation, using poly U-Sepharose column chromatography. They found that the $11 \mathrm{~S}$ component was actively synthesized with poly A-RNA from the seeds of early middle stages of maturation in a cell-free system using the wheat germ S-23 fraction. Such studies on protein synthesis in a cell-free system constructed of soybean seed components and finer studies on the specificities of the protein components as antigen will provide clearer knowledge of the mechanism of storage protein synthesis and its regulation.

Acknowledgements. We wish to thank Dr. K. Saio and Dr. K. Hashizume, National Food Research Institute, for their valuable advices. We express our appreciation to Mr. K. Mikoshiba, Kikyogaharabranch, Nagano-prefecture Agricultural Experiment Station, for supplying stock seeds of soybean. Thanks are also due to Mrs. E. Yamazaki for her useful assistance.

\section{REFERENCES}

1) H. Taira and H. Taira, Proc. Crop. Sci. Japan, 40, 530 (1971).

2) I. Koshiyama, Agric. Biol. Chem., 36, 62 (1972).

3) W. E. F. Naismith, Biochim. Biophys. Acta, 16, 203 (1955).

4) I. Koshiyama, Cereal Chem., 45, 394 (1968).

5) W. J. Wolf and D. R. Briggs, Arch. Biochem.
Biophys., 85, 186 (1959).

6) W. J. Wolf, J. Agric. Food Chem., 18, 969 (1970).

7) I. Koshiyama, Tampakushitsu Kakusan Koso, Bessatsu (in Japanese), IV-27, 456 (1971).

8) N. Catsimpoolas, J. A. Kenney, E. W. Meyer and B. F. Szuhaj, J. Sci. Food Agric, 22, 448 (1967).

9) K. Kitamura, T. Takagi and K. Shibasaki, Agric. Biol. Chem., 40, 1837 (1976).

10) V. H. Thanh and K. Shibasaki, Biochim. Biophys. Acta, 490, 370 (1977).

11) N. Catsimpoolas and E. W. Meyer, Arch. Biochem. Biophys., 125, 742 (1968).

12) N. Catsimpoolas and C. Ekenstam, ibid., 129, 490 (1969).

13) K. Kondo, S. Mori and M. Kajima, Kyoto Daigaku Syokuryo Kagaku Kenkyujo Hokoku (in Japanese), 15, 37 (1954).

14) M. Asano and K. Shibasaki, Shokuhin Kogyo Gakkai-shi (in Japanese), 20, 126 (1973).

15) J. E. Hill and R. W. Breidenbach, Plant Physiol., 53, 747 (1974).

16) R. H. Burris and P.W. Wilson, "Methods in Enzymology," Vol. IV, ed. by S. P. Colowick and N. O. Kaplan, Academic Press Inc., New York, N.Y., 1957, p. 356.

17) A. M. Nash and W. J. Wolf, Cereal Chem., 44, 183 (1967).

18) B. J. Davis, Ann. N.Y. Acad. Sci., 121, 404 (1964).

19) K. Hashizume, N. Nakamura and T. Watanabe, Agric. Biol. Chem., 39, 1339 (1975).

20) K. Weber and M. Osborn, J. Biol. Chem., 244, 4406 (1969).

21) N. Catsimpoolas, Cereal Chem., 46, 369 (1969).

22) J. Freund, Ann. Rev. Microbiol., 1, 291 (1947).

23) G. Mancini, A. O. Carbonara and J. F. Heremans, Immunochemistry, 2, 235 (1965).

24) S. Ochiai-Yanagi, T. Takagi, K. Kitamura, M. Tajima and T. Watanabe, Agric. Biol. Chem., 41, 647 (1977).

25) L. Beever and R. Poulson, Plant Physiol., 49, 476 (1972). 